\title{
CHANGES IN THE ACID-BASE EQUILIBRIUM IN ESSENTIAL HYPERTENSION
}

\author{
By JEROME M. WALDRON AND FRANZ GOLDSTEIN
}

\begin{abstract}
(From the Department of Physiology, Jefferson Medical College, and the Division of Medicine,
\end{abstract} Pennsylvania Hospital, Philadelphia, Pa.)

(Submitted for publication July 30, 1951 ; accepted October 22, 1951)

In a study of a group of hospitalized patients in whom there was no reason to suspect a disturbed acid-base balance, it was found that a few patients had low blood $\mathrm{pH}$ values. The only factor in common to these patients with the low $\mathrm{pH}$ values was that all had essential hypertension. It has been demonstrated in human subjects that experimental hypertension can be produced with desoxycorticosterone when sodium chloride is administered simultaneously ( 1 ); that there is a relationship between the ratio of sodium to chloride in essential hypertension and the severity of the hypertension (2); and that the restriction of sodium chloride has a beneficial effect in the treatment of patients with essential hypertension (3). This evidence of changes in ionic equilibrium of the blood in patients with essential hypertension prompted further investigation to determine whether an increased hydrogen ion concentration of the arterial blood was common in this disease.

\section{MATERIAL AND METHODS}

A group of 49 patients was studied, consisting of 14 normotensive patients, 19 essential hypertensive patients with normal kidney function and 16 hypertensive patients with renal functional impairment. In the last group of patients the renal impairment was due to glomerulonephritis in two cases and secondary to essential hypertension in the remaining ones. In order to be classed as hypertensive the patients had to have a blood pressure exceeding $150 \mathrm{~mm}$. of $\mathrm{Hg}$ systolic and $90 \mathrm{~mm}$. of $\mathrm{Hg}$ diastolic after hospitalization for one week. The classification of normal kidney function was on a clinical basis. The clinical criteria used were a specific gravity of 1,020 or better in the morning sample and no evidence of nitrogen retention as revealed by a patient's blood urea nitrogen below $15 \mathrm{mg}$. per $100 \mathrm{cc}$. All of these patients were routine hospital admissions who were admitted for some condition other than hypertension. $\mathrm{Pa}$ tients were selected who were free of congestive failure and any pathological condition which might interfere with normal pulmonary ventilation. In addition, no patients were studied who were receiving any drug known to change the acid-base pattern. All patients were prepared as for measurement of the basal metabolic rate.

Samples of arterial and venous blood were obtained with a minimum of inconvenience to the patient in order to prevent emotional excitement and possible hyperventilation. In a few patients it was impossible to obtain both samples without exciting the patient or for some technical reasons, and therefore determinations on either arterial or venous blood are omitted. The arterial blood was drawn from the brachial artery into an oiled Luer-Lok syringe containing a small amount of neutral heparin and sodium fluoride and sealed with a soldered needle hub. Venous blood was obtained without stasis from a vein of the same arm. In order to ensure representative samples, $10 \mathrm{ml}$. portions of blood were collected in periods of one to one and one-half minutes.

All determinations of the $\mathrm{pH}$ were performed in triplicate at room temperature with a Cambridge $\mathrm{pH}$ meter using a standardized (Taylor) buffer solution with a $\mathrm{pH}$ of 7.38 as a reference solution. The blood samples were kept on ice until shortly before being used for the $\mathrm{pH}$ determination at which time they were warmed to room temperature by immersion into a water bath. Oxygen content, oxygen capacity and carbon dioxide content were determined on whole blood, in duplicate, by the method of Van Slyke and Neill (4). Hematocrits were determined by the conventional Wintrobe method. The partial pressures of carbon dioxide were calculated from the experimental data, using the nomograms of Van Slyke and Sendroy (5).

\section{RESULTS}

In Table I are presented the results of examination of 14 normotensive patients. It will be noted that in none of these patients is the arterial $\mathrm{pH}$ below 7.38 or does the carbon dioxide tension exceed $46 \mathrm{~mm}$. of $\mathrm{Hg}$. The mean $\mathrm{pH}$ of this group is 7.41 , the mean carbon dioxide tension $39.6 \mathrm{~mm}$. of $\mathrm{Hg}$. The last patient ( $\mathrm{S} . \mathrm{H}$.) had acute glomerulonephritis without hypertension and exhibited a normal venous blood $\mathrm{pH}$. (The arterial $\mathrm{pH}$ was not determined.) The figures in this table are not intended to provide conclusive statistical data of normals but are to serve as controls and as a check of the validity of the methods and techniques used. 
TABLE I

Results of studies on normotensive patients

\begin{tabular}{|c|c|c|c|c|c|c|}
\hline $\begin{array}{l}\text { Patientis } \\
\text { infitiols }\end{array}$ & 180 & $\begin{array}{l}\text { fil } \\
\text { arterfial } \\
\text { blood }\end{array}$ & $\begin{array}{l}\text { PA } \\
\text { ronous } \\
\text { blood }\end{array}$ & $\begin{array}{l}\mathrm{CO}_{2} \\
\text { content } \\
\text { arterial } \\
\text { blood }\end{array}$ & $\begin{array}{l}\text { Oesgen capacits (C) } \\
\text { or } \\
\text { Hematocrit (B) }\end{array}$ & $\begin{array}{c}\mathrm{pCO}_{2} \\
\text { arterind } \\
\text { plasing } \\
\text { (ontcolated) }\end{array}$ \\
\hline & J28. & inits & mits & $\begin{array}{l}\text { volumes } \\
\text { per cent }\end{array}$ & $\begin{array}{l}\text { Tol. per cent (C) } \\
\text { or por cent (B) }\end{array}$ & mo of $\mathrm{Bg}$ \\
\hline 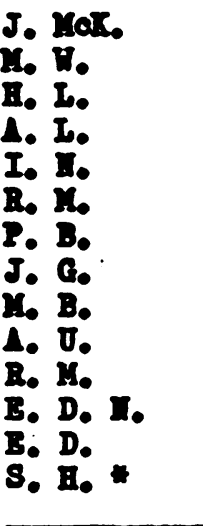 & $\begin{array}{l}64 \\
53 \\
54 \\
45 \\
62 \\
51 \\
61 \\
53 \\
59 \\
60 \\
52 \\
65 \\
46 \\
38\end{array}$ & $\begin{array}{l}7.39 \\
7.40 \\
7.44 \\
7.39 \\
7.40 \\
7.39 \\
7.48 \\
7.51 \\
7.47 \\
7.38 \\
7.40 \\
7.39 \\
7.41\end{array}$ & $\begin{array}{l}7.38 \\
7.37 \\
7.37 \\
7.37 \\
7.39\end{array}$ & $\begin{array}{l}57.85 \\
47.90 \\
44.77 \\
44.78 \\
46.72 \\
49.20 \\
52.64 \\
44.59 \\
48.46 \\
49.94 \\
42.48 \\
49.26 \\
51.05 \\
(55.18 \\
70 n 003)\end{array}$ & $\begin{array}{ll}34.0 & (\mathrm{~B}) \\
17.35 & (\mathrm{C}) \\
18.17 & (\mathrm{C}) \\
14.78 \\
22.04 \\
21.17 \\
21.85 \\
20.17 \\
17.95 \\
41.0 \\
32.0 \\
43.0 \\
21.0 \\
46 \\
46.0\end{array}$ & $\begin{array}{l}46 \\
42 \\
35 \\
37 \\
40 \\
43 \\
39 \\
31 \\
40 \\
44 \\
34 \\
42 \\
42\end{array}$ \\
\hline
\end{tabular}

- Patient with acuto glomerulonophritis

TABLE II

Results of studies on patients with essential hypertension without clinical evidence of renal impairment

\begin{tabular}{|c|c|c|c|c|c|c|c|}
\hline Patient & 280 & $\begin{array}{c}\text { pidial } \\
\text { blood }\end{array}$ & $\begin{array}{c}\text { ri! } \\
\text { ronous } \\
\text { blood }\end{array}$ & $\begin{array}{l}\mathrm{CO}_{2} \\
\text { content } \\
\text { artorial } \\
\text { blood }\end{array}$ & $\begin{array}{c}\text { Oaggen cap } \\
\text { or } \\
\text { Hematocrs }\end{array}$ & $\begin{array}{l}\text { acito (C) } \\
\text { it (H) }\end{array}$ & $\begin{array}{c}\mathrm{pCO}_{2} \\
\text { arterial } \\
\text { plasina } \\
\text { (aicuinted) }\end{array}$ \\
\hline \multirow{6}{*}{ 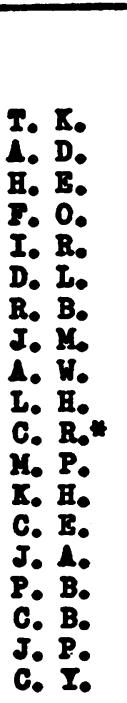 } & J250. & minits & mits. & $\begin{array}{l}\text { volumes } \\
\text { per cent }\end{array}$ & \multicolumn{2}{|c|}{$\begin{array}{l}\text { rol. per cont (C) } \\
\text { or per cont (B) }\end{array}$} & mof of $\overline{\text { Bg }}$ \\
\hline & \multirow{2}{*}{\multicolumn{2}{|c|}{$\begin{array}{ll}50 & 7.35 \\
51 & \\
60 & 7.35 \\
47 & 7.33 \\
59 & 7.34 \\
60 & 7.36\end{array}$}} & 7.31 & \multirow[b]{2}{*}{$\begin{array}{l}52.40 \\
52.64 \\
52.36 \\
49.10 \\
51.70\end{array}$} & \multirow{5}{*}{$\begin{array}{l}18.72 \\
15.95 \\
17.65 \\
22.27 \\
17.50 \\
16.50 \\
18.16 \\
36.5 \\
18.15 \\
31.0 \\
22.60 \\
27.0 \\
38.5 \\
41.0 \\
40.0 \\
38.0 \\
40.0 \\
45.0 \\
41.5\end{array}$} & \multirow{5}{*}{ 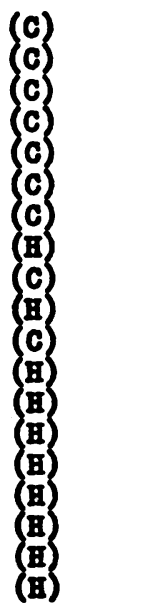 } & \multirow[b]{2}{*}{$\begin{array}{l}50 \\
49 \\
53 \\
46 \\
47\end{array}$} \\
\hline & & & \multirow{2}{*}{$\begin{array}{l}7.31 \\
7.26 \\
7.29 \\
7.32 \\
7.27 \\
7.47 \\
7.33\end{array}$} & & & & \\
\hline & $\begin{array}{l}49 \\
43 \\
59 \\
56 \\
28 \\
47\end{array}$ & $\begin{array}{l}7.34 \\
7.38 \\
7.34 \\
7.48 \\
7.36 \\
7.35\end{array}$ & & $\begin{array}{l}51.78 \\
50.48 \\
46.30 \\
48.97 \\
49.00\end{array}$ & & & $\begin{array}{l}52 \\
46 \\
43 \\
35 \\
43\end{array}$ \\
\hline & $2 \pi$ & 7.36 & 7.29 & 49.16 & & & 47 \\
\hline & $\begin{array}{l}62 \\
56 \\
59 \\
61\end{array}$ & $\begin{array}{l}7.34 \\
7.35 \\
7.37 \\
7.35 \\
7.35\end{array}$ & $\begin{array}{l}7.33 \\
7.34 \\
7.32 \\
7.32\end{array}$ & $\begin{array}{l}55.87 \\
51.85 \\
46.55 \\
55.30\end{array}$ & & & $\begin{array}{l}52 \\
48 \\
46 \\
49\end{array}$ \\
\hline 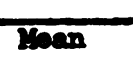 & 52. & 7.36 & 7.32 & 51.04 & & & 47 \\
\hline
\end{tabular}

wPatient with suopoctod phooluranocytom 
The results of the studies on patients with essential hypertension and normal kidney function are presented in Table II. In this group, with one exception, the arterial $\mathrm{pH}$ values range between 7.33 and 7.38, and the arterial carbon dioxide partial pressure varies between 43 and $53 \mathrm{~mm}$. of $\mathrm{Hg}$ with a mean of 47.4 . The mean $\mathrm{pH}$ of this group is 7.36. This represents a 12 per cent increase in hydrogen ion concentration in the hypertensive group. The differences in $\mathrm{pH}$ between normotensive and hypertensive patients of this group, although slight, are consistent and exceed a probability of 0.01 . One patient (C. R.) does not exhibit these changes. This patient was suspected, clinically, of having a pheochromocytoma. Although the patient died, an autopsy could not be performed and the diagnosis was never substantiated; therefore this case has been included with the group having essential hypertension.

Patients with hypertension and renal impairment, listed in Table III, also have low arterial pH values ranging from 7.23 to 7.37 , but the carbon dioxide tensions are normal or below normal with a mean of $39.1 \mathrm{~mm}$. of $\mathrm{Hg}$. The mean arterial $\mathrm{pH}$ of this group is 7.31. The first two patients listed in the table have hypertension secondary to chronic glomerulonephritis; three patients (L. B., G. J., M. J.) have the malignant form of essential hypertension. The remaining patients have prolonged hypertension with secondary renal functional impairment of varying degrees, as evidenced by variations in the ability to concentrate urine and variations in degree of nitrogen retention.

\section{DISCUSSION}

For some time, the range of blood $\mathrm{pH}$ from about 7.30 to 7.50 was accepted as normal (6). Recent studies $(7,8)$ indicate a narrower range of normal values from 7.37 to 7.45 . This change is due to refinements in the technique for measuring hydrogen ion concentration which were not available to the earlier investigators, and also to the elucidation of many factors which were sources of error in collecting and handling of the blood prior to the determination. Other factors which helped to account for the previously accepted wide spread of normal are not within the scope of the present paper but some of them will be mentioned

TABLE III

Results of studies on patients with hypertension and renal functional impairment

\begin{tabular}{|c|c|c|c|c|c|c|}
\hline $\begin{array}{l}\text { Paticent's } \\
\text { inftials }\end{array}$ & 180 & $\begin{array}{l}\text { Pi } \\
\text { arterial } \\
\text { blood }\end{array}$ & $\begin{array}{l}\text { pil } \\
\text { benous } \\
\text { blood }\end{array}$ & $\mathrm{CO}_{2}$ & $\begin{array}{l}\text { orvion capraits (C) } \\
\text { or } \\
\text { Bomacrit (B) }\end{array}$ & $\mathrm{pton}_{\text {artarial }}$ \\
\hline & 5r8. & units & units & por cent & $\begin{array}{l}\text { vol. per cent (C) } \\
\text { or per cont (B) }\end{array}$ & m. \\
\hline 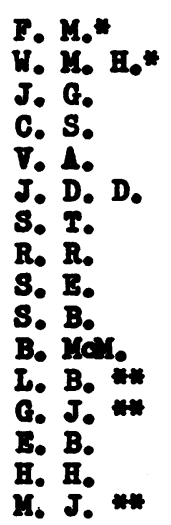 & $\begin{array}{l}46 \\
50 \\
47 \\
63 \\
64 \\
62 \\
45 \\
54 \\
56 \\
59 \\
53 \\
36 \\
34 \\
64 \\
65 \\
42\end{array}$ & $\begin{array}{l}7.33 \\
7.26 \\
7.32 \\
7.35 \\
7.35 \\
7.34 \\
7.29 \\
7.36 \\
7.33 \\
7.37 \\
7.25 \\
7.27 \\
7.32 \\
7.30 \\
7.23\end{array}$ & $\begin{array}{l}7.32 \\
7.23 \\
7.33 \\
7.33 \\
7.33 \\
7.22 \\
7.30 \\
7.31 \\
7.35 \\
7.23 \\
7.22 \\
7.30\end{array}$ & $\begin{array}{l}38.04 \\
24.20 \\
49.91 \\
46.65 \\
50.78 \\
46.10 \\
31.20 \\
41.76 \\
44.27 \\
44.50 \\
35.43 \\
29.30 \\
45.25 \\
43.61 \\
29.98\end{array}$ & 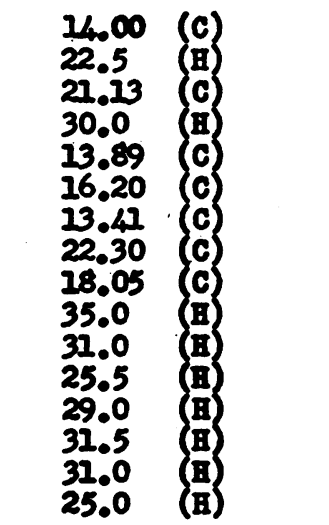 & $\begin{array}{l}36 \\
26 \\
51 \\
41 \\
47 \\
41 \\
34 \\
38 \\
42 \\
39 \\
39 \\
30 \\
44 \\
44 \\
34\end{array}$ \\
\hline 500 & 52.4 & .31 & .28 & 9.93 & & 39.1 \\
\hline
\end{tabular}

- Patients with huperticiaion secondary to glonorulonophritis

* Patients with the mligenat fors of escoutel in upertematon 
TABLE IV

Statistical significance of differences between groups

\begin{tabular}{|c|c|c|c|c|c|c|}
\hline & \multicolumn{2}{|c|}{ Groups 1 and 2} & \multicolumn{2}{|c|}{ Groups 2 and 3} & \multicolumn{2}{|c|}{ Groups 1 and 3} \\
\hline & $t \operatorname{scos} \theta$ & $\mathbf{p}$ & $t$ se010 & $\mathbf{p}$ & $t$ score & $\mathbf{p}$ \\
\hline pl of arterial blood & 3.70 & $>0.01$ & 3.65 & $>0.01$ & 6.45 & $>0.01$ \\
\hline pli of renous blood & 4.12 & $>0, \boldsymbol{n}$ & 3.4 & $>0 . \boldsymbol{n}$ & 4.02 & $>0 . \boldsymbol{\alpha}$ \\
\hline $\mathrm{O}_{2}$ content of arterial blood & 2.04 & 0.05 & 4.60 & $>0.01$ & 2.92 & $>0.01$ \\
\hline $\mathrm{pCO}_{2}$ of arterial plasma (calc.) & 4.72 & $>0.0$ & 4.23 & $>0.01$ & 0.229 & $<0.50$ \\
\hline
\end{tabular}

Group 18 Hormotensive patients.

Group 28 Patients with essential hypertension without clinical evidence of renal impairment.

Group 3: Hypertensivo patients with renal runctional impairment.

in explanation of the procedure used in this study.

Study of the patients under basal conditions eliminated some of these sources of error since the diet or degree of activity prior to obtaining the blood sample may affect the acid-base pattern slightly (7). Hospitalizing the patients for one week prior to study definitely established the diagnosis of sustained hypertension and allowed them to become accustomed to the procedure of venipuncture. This tended to eliminate any excitement with resulting increase in ventilation which would have lowered the carbon dioxide tension and raised the $\mathrm{pH}$ of the blood, with a tendency to obscure the abnormalities found in this study.

The differences in $\mathrm{pH}$ and carbon dioxide tensions between the normotensive and the hypertensive group with normal kidney function cannot be explained by the present study: They are, nonetheless, of definite statistical significance (Table IV). They cannot be due to differences in age groups since the average age and age distribution are nearly identical in all three groups. It has been shown (9) that the $\mathrm{pH}$ of the arterial blood progressively decreases with age but it is not below 7.38 at the age of 65 . The differences may be due to early changes in renal physiology because the classification of these patients as having normal kidney function is based on the clinical evidence of no nitrogen retention and the ability to concentrate the urine. Goldring and Chasis (10) have shown that there are changes in renal physiology which precede changes in these two functions of the kidney.

The patients in the group of essential hypertension with normal kidney function presented an increased partial pressure of carbon dioxide accompanying the increased blood acidity. This is the pattern of primary respiratory acidosis. The increased acidity of the arterial blood with a decrease in the partial pressure of carbon dioxide in patients with hypertension and renal impairment is the typical picture of metabolic acidosis, whereby fixed acids accumulate in the blood with a consequent lowering of the carbon dioxide tension due to respiratory compensations. In our patients with renal impairment secondary to essential hypertension the carbon dioxide tension is not as low as predicted by the formula of Gray (11). In the present study the difference in partial pressure of carbon dioxide in arterial plasma between the normotensive group and the group of hypertensives with renal impairment is not statistically significant (Table IV).

\section{SUM MARY}

Evidence is presented that patients with essential hypertension and normal kidney function have a higher hydrogen ion concentration and a higher partial pressure of carbon dioxide in the arterial blood than normotensive individuals. In 
the normotensive group the $\mathrm{pH}$ was found to be 7.38 or higher, with a mean of 7.41 , while the hypertensive patients have a $\mathrm{pH}$ of the arterial blood of 7.38 or below, with a mean of 7.36. This increased acidity of the blood in patients with hypertension and normal kidney function is accompanied by an increased carbon dioxide tension which averages $47.4 \mathrm{~mm}$. of $\mathrm{Hg}$, compared to $39.6 \mathrm{~mm}$. in the normotensive group. When renal impairment secondary to essential hypertension occurs, the acid-base pattern approaches that of metabolic acidosis.

\section{REFERENCES}

1. Perera, G. A., and Blood, D. W., Pressor activity of desoxycorticosterone acetate in normotensive and hypertensive subjects. Ann. Int. Med., 1947, 27, 401.

2. Selye, F. L., Biochemical changes in hypertension. Canad. M. A. J., 1947, 57, 325.

3. Grollman, A., Harrison, T. R., Mason, M. F., Baxter, J., Crampton, J., and Reichsman, F., Sodium restriction in the diet for hypertension. J. A. M. A., 1945, 129, 533.

4. Van Slyke, D. D., and Neill, J. M., The determination of gases in blood and other solutions by vacuum extraction and manometric measurement. J. Biol. Chem., 1924, 61, 523.

5. Van Slyke, D. D., and Sendroy, J., Jr., Studies of gas and electrolyte equilibria in blood; line charts for graphic calculations by the Henderson-Hasselbalch equation, and for calculating plasma carbon dioxide content from whole blood content. J. Biol. Chem., 1928, 79, 781.

6. Peters, J. P., and Van Slyke, D. D., Quantitative Clinical Chemistry. Vol. I. Interpretations. Williams \& Wilkins Co., Baltimore, 1931, pp. 936, 940, and 941.

7. Shock, N. W., and Hastings, A. B., Studies of the acid-base balance of the blood. III. Variations in the acid-base balance of the blood in normal individuals. J. Biol. Chem., 1934, 104, 585.

8. Wilson, R. H., The $\mathrm{pH}$ of whole arterial blood. J. Lab. \& Clin. Med., 1951, 37, 129.

9. Shock, N. W., and Yiengst, M. J., Age changes in the acid-base equilibrium of the blood of males. Gerontology, 1950, 5, 1.

10. Goldring, W., and Chasis, H., Hypertension and Hypertensive Disease. The Commonwealth Fund, New York, 1944.

11. Gray, J. S., Pulmonary Ventilation and its Physiological Regulation. Charles C Thomas, Springfield, Ill., 1950, p. 37. 